"Mircea cel Batran" Naval Academy Scientific Bulletin, Volume XIX - 2016 - Issue 1

Published by "Mircea cel Batran" Naval Academy Press, Constanta, Romania // The journal is indexed in:

PROQUEST / DOAJ / DRJI / JOURNAL INDEX / I2OR / SCIENCE LIBRARY INDEX / Google Scholar / Crossref /

Academic Keys / ROAD Open Access / OAJI / Academic Resources / Scientific Indexing Services / SCIPIO

\title{
ABOUT THE MAINTENANCE OF THE RADIAL AND AXIAL SHAFT BEARINGS FROM PROPULSION PLANT WITH GAS AND STEAM TURBINES
}

\author{
Ion Adrian GIRBA ${ }^{1}$ \\ Dorin-Silviu BANU² \\ Anastase PRUIU 3 \\ Daniel MARASESCU \\ ${ }^{1} \mathrm{PhD}$ attendee Eng. Military Tehnical Academy \\ ${ }^{2} \mathrm{PhD}$ attendee Eng. Military Tehnical Academy \\ ${ }^{3}$ Professor PhD Eng., Marine Engineering and Naval WeaponsDepartament \\ ${ }^{4} \mathrm{PhD}$ attendee Eng., Marine Engineering and Naval WeaponsDepartament
}

\begin{abstract}
The paper presents the main rules imposed by classification societies for design the shaft for propulsion plant with gas and steam turbines. It also analyzes the main maintenance activities to ensure their safe operation.
\end{abstract}

Key words: turbine, bearing, maintenance, vibration.

\section{INTRODUCTION}

The naval gas turbines were and are used in propulsion plants on military ships. As time goes the applied research in the field of naval it showed that gas turbines can be used in propulsion installations in combination with other gas turbines,or combined with diesel engines or steam turbines which can be equipped comercial ships also, like fast transient passenger or cargo ships, LNG ships (where in combination with steam turbines, gas turbines have developed a very good yield reported at fuel consumption and performance of speed and power developed).

Naval propulsion plants with gas turbines ( NPPGT) experienced a continuous development on ships, found it separately or in multiple combined cycles configurations, depending on the operational characteristics of the vessel. The main constructive configurations of NPPGT are:

- CODOG(COmbined Diesel Or Gas turbine),

- CODAG (COmbined Diesel And Gas turbine),

- CODELAG (COmbined Diesel-Eectric and Gas turbine ),

- COGOG (COmbined Gas Or Gas turbine),

- COGAG (COmbined Gas And Gas turbine),

- COGAS (COmbined Gas And Steam turbine)

- COGES (COmbined Gas Electrical Steam turbine). They are used on board of commercial and military vessels. Naval propulsion plants type COGAS, according to research in the field, can yield up to $60 \%$.

THE BEARINGS USED IN GAS AND STEAM TURBINES MANUFACTURE

The bearings usually are plain bearings for large turbines, but becouse the naval gas turbines are derived from the turbines used in aviation the bearings we will find coud be rolling bearings.
The bearings design and location should result in a longer in service, reliability and economic efficiency. To reach this benchmark must consider the following factors:

- load and speed;

- working temperature;

- lubrication;

- shaft location;

- service time;

- assembly/disassembly;

- noise;

- environmental conditions.

Plain bearings are divided into two categories depending on the direction of the loading force:

- radial bearings;

- thrust bearings.

Radial bearings according to the power turbine are :

- lubricated bearings with rings used up to 5 bars pressure at low power turbine at speed slip-one up to $12 \mathrm{~ms}^{-1}$;

- bearings lubricated under pressure, having high sliding speeds that can reach about $60 \div 80 \mathrm{~ms}^{-1}$, used in high power turbine and thus incurring high pressures that can reach a average pressure of 20 bar on the journal.

- The efficiency of these two types of bearings have two basic elements, the material from which are made the two bodies, the bearings liner and the journal in rotation, and the quality of the lubricant (oil in turbines case). Considering these elements, based on hydrodynamic theory of lubrication, were established the relations through which one can calculate the lubricant film pressure distribution self-supporting.

Since the oil layer which is in contact with the bearing (bush) has zero velocity, and the one which is in contact with the journal has the speed thereof, the intermediate layers have different 
"Mircea cel Batran" Naval Academy Scientific Bulletin, Volume XIX - 2016 - Issue 1

Published by "Mircea cel Batran" Naval Academy Press, Constanta, Romania // The journal is indexed in: PROQUEST / DOAJ / DRJI / JOURNAL INDEX / I2OR / SCIENCE LIBRARY INDEX / Google Scholar / Crossref /

Academic Keys I ROAD Open Access / OAJI / Academic Resources / Scientific Indexing Services / SCIPIO

speeds between zero and the journal shaft speed. Due to the rotation of the spindle, the lubricant layer is driven in the interstice between the spindle and bushings. Because the surface between the bearing and the journal shaft is tapering in interstitial area, there is an increase of oil pressure generating hydrodynamic force for self-supporting which interrupting contact between the journal and bearing liner. Thus according to oil pressure whitch generates hydrodynamic force, calculate the load force of the journal, the eccentricity of journal in bearing and bearing oil film thickness must be at least greater than the sum between maximum roughness of bearing and spindle surfaces. In the figure $1 a$ is shown the pressure distribution on the circumference of the bearing, and in the figure $1 b$ is shown the distribution of pressure along the length of the bearing liner.

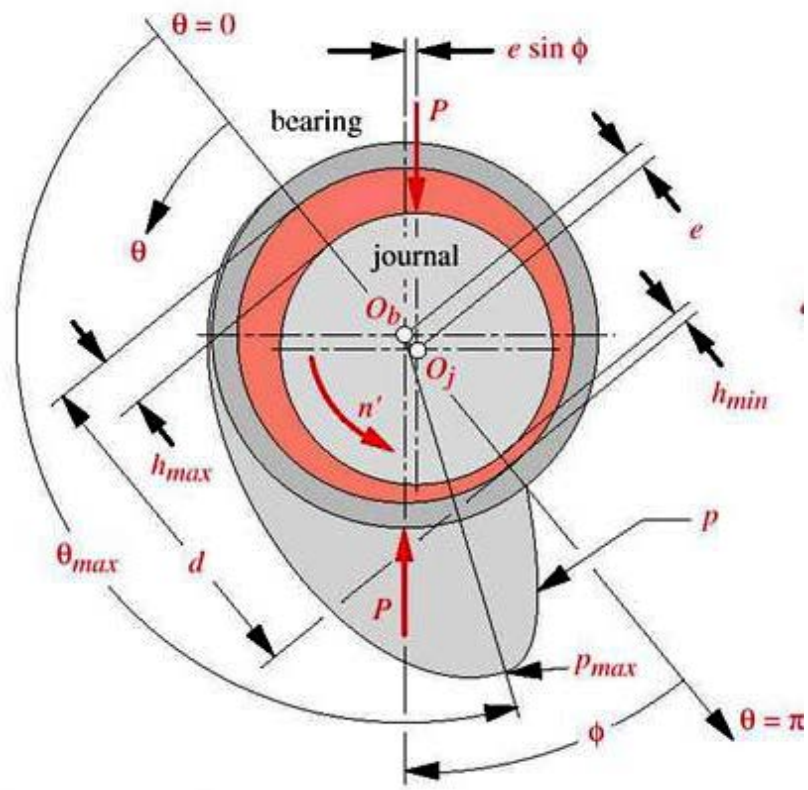

Fig.1a - the pressure distribution on the circumference of the bearing liner [9];

$n$-journal speed; $d$ - the inner diameter of the bearing liner; $d_{j}$ - diameter of the journal (fig. b); $P$ - radial force or load force of journal; $h_{\text {min }}$ - the minimum oil film thickness; $h_{\max }$ - maximum oil film thickness; $p$ - average pressure; $p_{\text {max }}$ maximum pressure; e- eccentricity

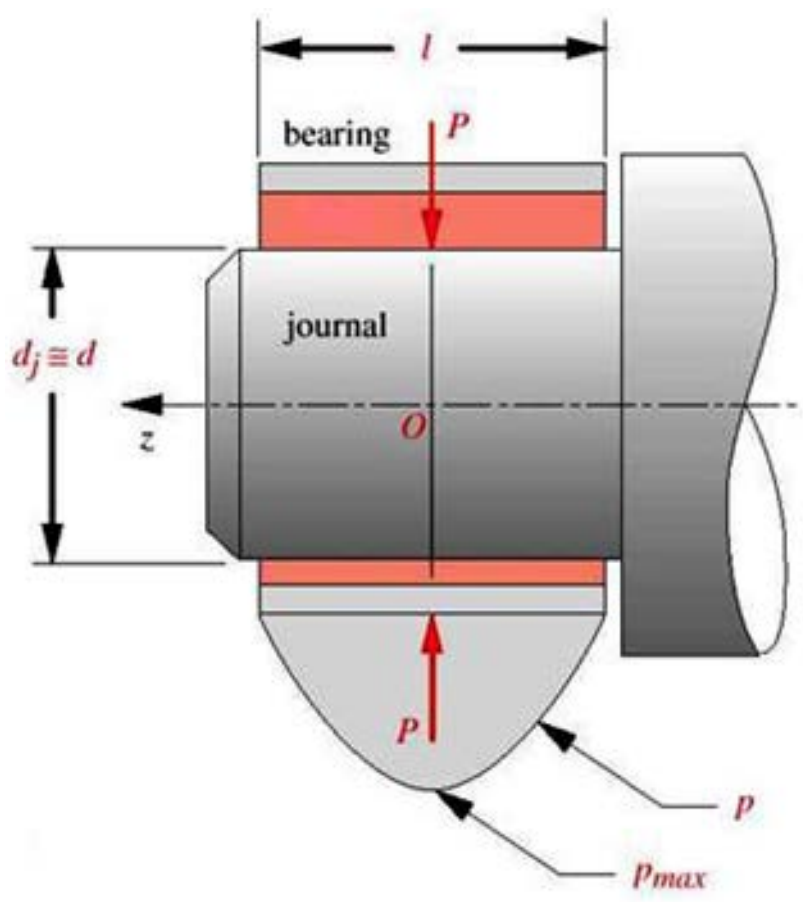

Fig.1b - Contact pressure distribution along the length (I) [9]

In some cases for a beter eficiency stability of the journal in bearing liner and rotor vibration damping was chosen the plain bearing in the lemon shape which has two bearing surfaces, both above and below. The average pressure of the bearing is determined by the relationship (1):

$$
\begin{gathered}
p=\frac{p}{d_{\rho^{d}}} \leq p_{a}, \quad(1), \text { where } p_{a} \text { is admissible } \\
\text { pressure }
\end{gathered}
$$

So can do the calculation of wear:

$V_{u}=k \cdot P \cdot L \quad(2)$,

- $V_{u}$ - the volume of material removed by wear,or wear volume accepted;

- $k$ - coefficient expressing the proportionality between the material couple and lubrication conditions;

- $P$ - radial force resulting from the relationship (1) $;$

- $L$ - the length done by the journal in the relative motion in relation to bearing during operation period imposed.

$$
\begin{aligned}
& L=v \cdot L_{h}(3), \\
& v=\pi \cdot d_{j} \cdot n(4),
\end{aligned}
$$

represent the journal speed, where $\mathrm{n}$ is the journal speed and, iar $L_{h}$ represents operating period imposed

The equation (1) becomes: 
"Mircea cel Batran" Naval Academy Scientific Bulletin, Volume XIX - 2016 - Issue 1

Published by "Mircea cel Batran" Naval Academy Press, Constanta, Romania // The journal is indexed in:

PROQUEST / DOAJ / DRJI / JOURNAL INDEX / I2OR / SCIENCE LIBRARY INDEX / Google Scholar / Crossref /

Academic Keys / ROAD Open Access / OAJI / Academic Resources / Scientific Indexing Services / SCIPIO

$$
\begin{aligned}
& V_{u}=k \cdot p_{m} \cdot l \cdot d_{j} \times v \cdot L_{h}=K^{*} \cdot p_{m} \times(5), \text { and: } \\
& K^{*}=k \cdot l \cdot d_{j} \cdot L_{h}
\end{aligned}
$$

For acceptable wear volume $V_{u}$ and an operating period imposed $L_{h}$ resulting allowable bearing liner value represented by the product $p_{m a} V_{a}$.

Calculation of wear is to compare the actual value with which admissible:

$$
p_{m} \times v \leq p_{m a} \times v_{\alpha}\left[\mathrm{MPa} \cdot \mathrm{ms}^{-1}\right](7), \text { where }
$$

the permissible values given in the literature are based on the bearing material. Since the power consumed by friction is found in the relation $p_{m} v$ , it can do a calculation of the average temperature.

Thus for fluid friction, a convetional coefficient of friction $\mu$ is defin.

$$
\begin{aligned}
& \mu=\frac{\eta v}{p_{m} \cdot h_{\min }} \text { (8), } \\
& \eta \text { - dynamic viscosity of the lubricant; } \\
& v \text { - speed spindle; } \\
& p_{m} \text { - average pressure; } \\
& h_{\min } \text { - the thickness of the fluid layer. } \\
& F_{f} \cdot v=\mu \cdot P \cdot v=K \cdot A \cdot\left(t-t_{0}\right) \\
& t=t_{0}+\frac{\mu \cdot P \cdot v}{K \cdot A} \leq t_{\alpha} \quad(10),
\end{aligned}
$$

- $F_{f}$ - the power consumed by friction;

- $t$ - average temperature;

- to - ambient temperature;

- $t_{a}$ - allowable temperature;

- $\mu$ - friction coefficient;

- $K$ - overall coefficient of heat transfer through the bearing housing;

- $A$ - the outer surface of the bearing body in contact with air.

At high power turbines can meet journal bearings with two pivoted shoe journal bearing surfaces, or three, four or more surfaces for high speeds. In figure 2 is a pivoted shoe journal bearing, which proved to be the best solution for the elimination of the phenomenon of oil whirl..

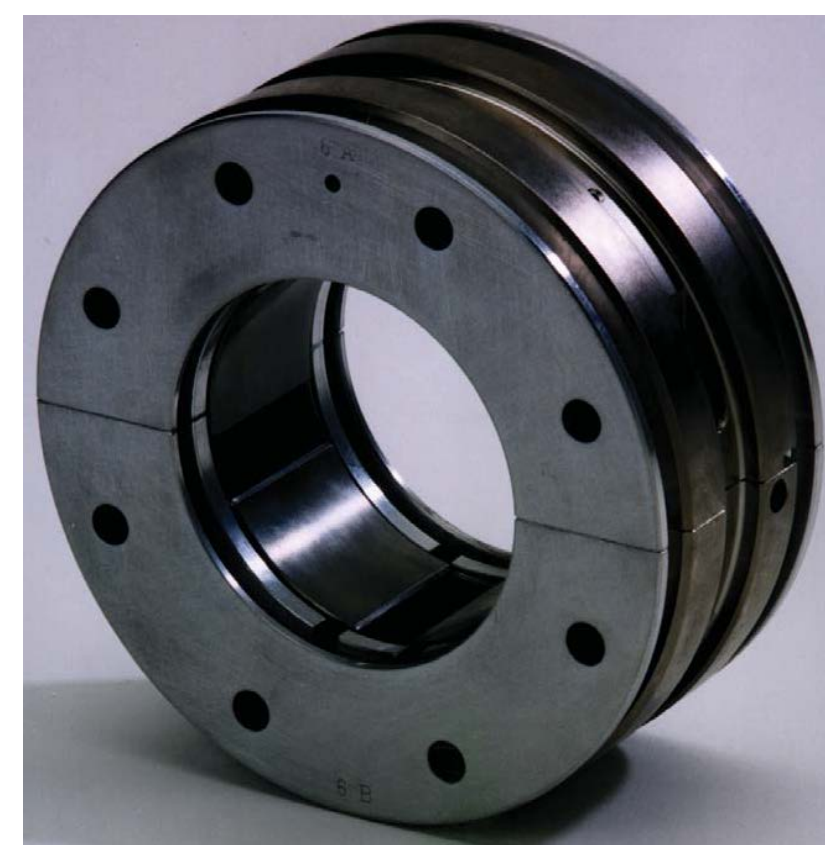

Figure 2 - Hydrodynamic Pivoted Shoe Journal Bearing [12,pg.5]

For very heavy shafts is important the positioning mode of pivots so loading force on the journal does not act between the journal shoes. Thus, in figure 3 it can be seen the effects of the conditions described above, it prevents formation of the bearing film and cause damage to the bearing and shaft, the journal shoes surfaces will corrode, and eccentricity will increase. Relocation shaft in a pivoted shoe journal bearing while rotating between journl shoes will produce vibrations (figure 3 -right position).

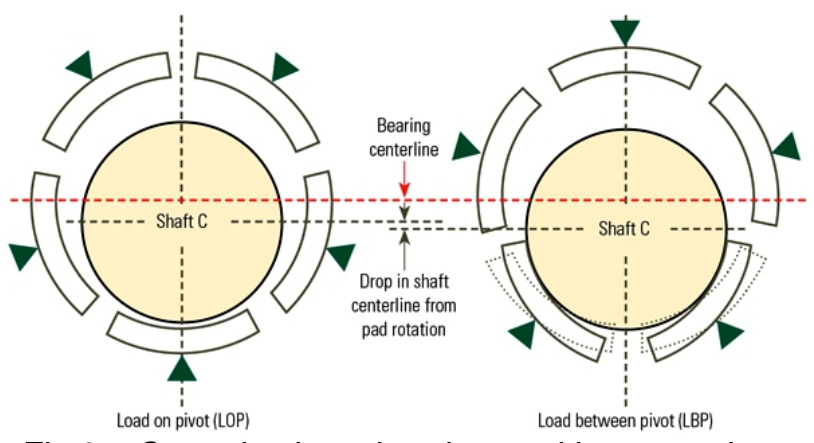

Fig. 3 - Corectly pivots bearing pozition mounting for eliminate high vibrations and bearing and shaft damanges [7]

Axial bearings are used for taking over the axial forces acting on the rotor. They may be:

- at high power turbine bearings rings with one disc;

- at low power turbines, bearings with shaft collar on each side of the liner thrust bearing for withstanding axial. 
"Mircea cel Batran" Naval Academy Scientific Bulletin, Volume XIX - 2016 - Issue 1

Published by "Mircea cel Batran" Naval Academy Press, Constanta, Romania // The journal is indexed in: PROQUEST / DOAJ / DRJI / JOURNAL INDEX / I2OR / SCIENCE LIBRARY INDEX / Google Scholar / Crossref /

Academic Keys / ROAD Open Access / OAJI / Academic Resources / Scientific Indexing Services / SCIPIO

In figure 4 compares the types of axial bearings by loading capability, adaptability to rotate in both directions of rotation, tolerance to changing conditions like load / speed, eccentricity tolerance, volume.

Bearings with pressure grooves are used rarely at any continuous load, but are useing if axial loading is very short or occurs at rest or only at low speeds.

Tapered thrust bearings can withstand a load equal to that borne by oscillating thrust bearings.

\begin{tabular}{|c|c|c|c|c|c|}
\hline BEARING TYPE & $\begin{array}{c}\text { LOAD } \\
\text { CAPACITY } \\
\end{array}$ & 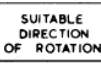 & 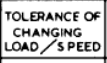 & \begin{tabular}{|c|} 
TOLERANCE \\
Oo \\
MISALIGMMENT \\
\end{tabular} & $\begin{array}{l}\text { SPACE } \\
\text { SROOURTM TT }\end{array}$ \\
\hline & POOR & $\infty$ & 6000 & MODEAATE & СОМРАст \\
\hline BDIPECC TONAC & MODERATE & 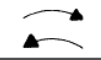 & POOR & POOR & СОМРАCT \\
\hline UNDORECTIONAL & 6000 & $\rightarrow$ & POOR & POOR & compact \\
\hline AODRECTIONAL & 6000 & $\infty$ & 6000 & 6000 & COEATER \\
\hline UNIDIRECTIONAL & 6000 & 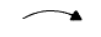 & 6000 & 6000 & cosater \\
\hline
\end{tabular}

Fig.4 - Comparison of thrust-bearing types [ 13 ,pg.491]

At the thrust bearings the power consumption can be calculated and taken into account the loss of turbine efficiency, so the lubrication system shoud designed so as to mitigate as much as possible this unwanted effect. These losses usually have values between $0.8 \div 1 \%$. In the diagram from figure 5 is seeing power losses due to the turbine shaft thrust bearing according to its diameter and spindle speed.

Load variations cause axial forces acting forwards and backwards to compressor and to turbine. Thus the shaft is always under axial tension depends by load variations acting on the thrust bearing fixed in the static housing. Control of proper loading of the thrust bearing is made by means of a pressure equalization ring of fixed diameter, on which acts the pressure of the internal air into the compressor (see figure 6).

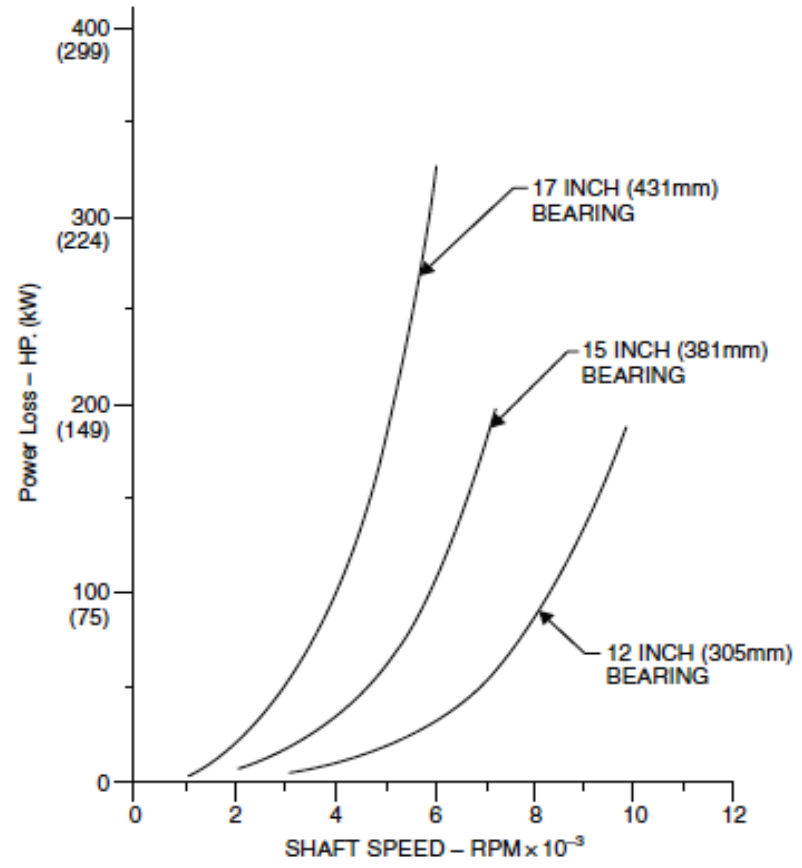

Fig.5 - Total power loss in thrust bearings [ 13 ,pg.494]

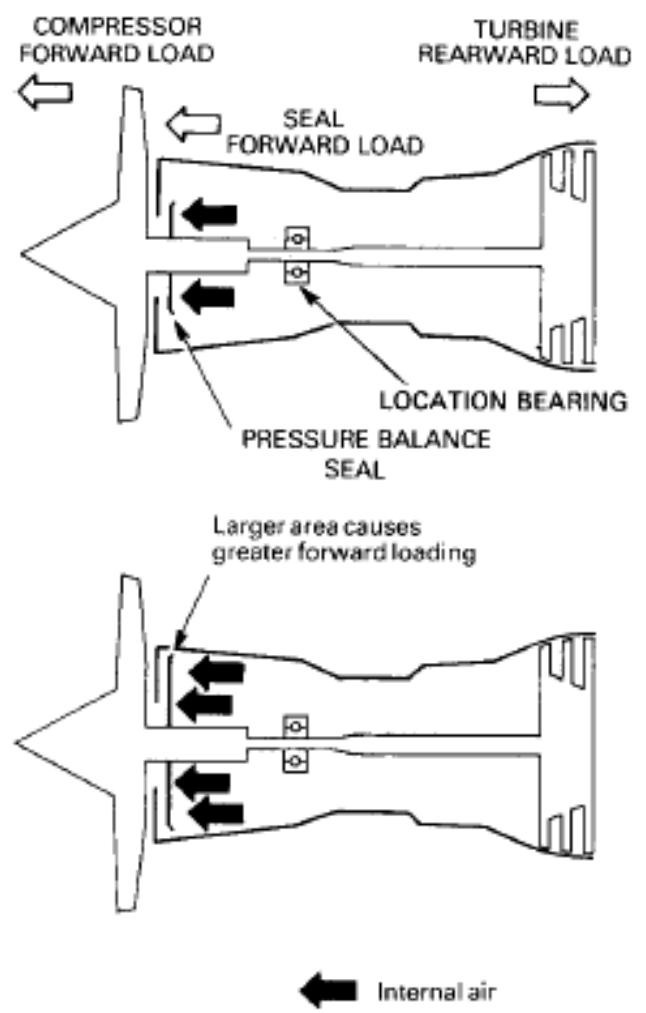

Fig.6 - Control of axial bearing load [6,pg.172]

In figure 7 it can see the arrangement of axial and radial bearings in a marine propulsion system with a steam turbine.

Rolling bearings are used in naval propulsion plants with gas turbines where the turbines derived from aviation ( naval gas turbines). 
"Mircea cel Batran" Naval Academy Scientific Bulletin, Volume XIX - 2016 - Issue 1

Published by "Mircea cel Batran" Naval Academy Press, Constanta, Romania // The journal is indexed in: PROQUEST / DOAJ / DRJI / JOURNAL INDEX / I2OR / SCIENCE LIBRARY INDEX / Google Scholar / Crossref /

Academic Keys I ROAD Open Access / OAJI / Academic Resources / Scientific Indexing Services / SCIPIO

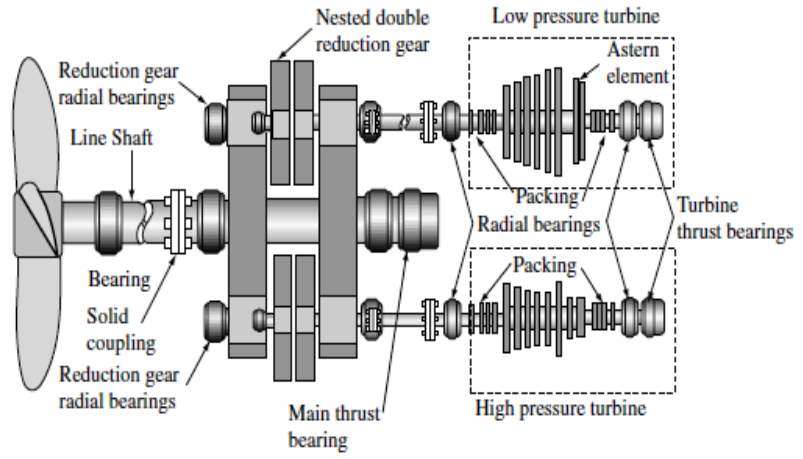

Fig.7 - Typical arrangement of naval gearedturbine propulsion plant [15, pg.14]

At their design take into account the duration of the service to be over 100,000 hours, but in practice it is recommended to replace them after 50,000 hours of operation for turbo-generators, and for power turbines acting mechanical the propeller, the replacement is recommended after 100,000 operating hours. Rolling Ball bearings have a lower load capacity, but supports higher speeds and rolling roller bearings support a higher load capacity, but works at lower speeds.

Rolling bearings like the plain bearing depending on the direction of load forces are diveded in radial bearings and thrust bearings.

In figure 8 are exemplificate both types of rolling bearings radial and axial, ball or roller used at gas turbines.

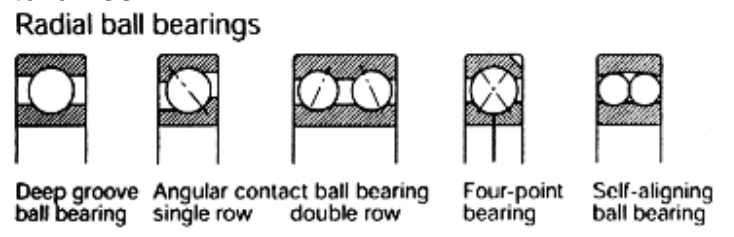

Radial roller bearings

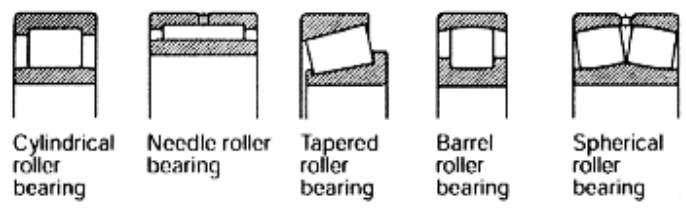

Thrust ball bearings

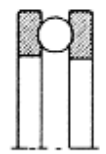

Thrust ball bearing

Thrust roller bearings

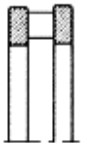

Cylindrical roller thrust bearing Spherical roller thrust bearing

Fig. 8 - Types of roller bearings used in the construction of gas turbines [13,pg. 470]
Since the ship is being built under the standards required by ship classification societies (naval registers), it will find standardized rules for shafts and bearings of naval propulsion systems turbines .

\section{AUTHORITIES AND CLASSIFICATION SOCIETIES}

Classification societies have emerged in shipping as non-governmental organizations, which were aimed at establishing and maintaining technical standards for the construction and operation of ships and maritime facilities adjacent coasts.

The main role of these companies is to classify vessels and validate their design and construction in accordance with applicable standards and their periodic inspection. All classification societies are responsible for classifying all structures installed offshore and underwater. [2]

There are currently over fifty classification ships societies, but thirteen of them are members of IACS (International Association of Classification Societies). IACS members, in alphabetical order, are: American Bureau of Shipping-ABS, Bureau Veritas-BV, China Classification Society-CCS, Croatian Register of Shipping-CRS, Det Norske Veritas Germanischer Lloyd-DNV-GL, Germanischer Lloyd-GL, Indian Register of Shipping-IRS, Korean Register of Shpping-KR, Lloyd's-LR, Nippon Kaiji Kiokai-NK/ClassNK, Polish Register of Shipping-PRS, Registro Italiano Navale-RINA, Russian Maritime Register of Shipping-RS.

IACS has its origins in the International Load Line Convention of 1930.

Convention recommended collaboration between classification societies to ensure „....as much uniformity as possible in the application of the standards of strength upon which freeboard is based.."[11].

Rules Imposed by Classification Societies for Shafts And Bearings Design of Marine Propulsion Plants Whith Turbines

The classification societies creates specific rules for design, construction and materials that should be used with precise reference to fixed and mobile elements that are turbine shafts. Making an example after french classification society, Bureau Veritas established in 1828, we find the following rules:

A) Steam Turbine :

a) materials for elements witch are in rotating movement:

- rotors, shafts and discs must be made of forged steel with a tensile strength within in the limits imposed by the classification society based by composition of the steel;

- small turbine rotors made from special cast steel; 


\section{"Mircea cel Batran" Naval Academy Scientific Bulletin, Volume XIX - 2016 - Issue 1 \\ Published by "Mircea cel Batran" Naval Academy Press, Constanta, Romania /I The journal is indexed in: PROQUEST / DOAJ / DRJI / JOURNAL INDEX / I2OR / SCIENCE LIBRARY INDEX / Google Scholar / Crossref / \\ Academic Keys / ROAD Open Access / OAJI / Academic Resources / Scientific Indexing Services / SCIPIO}

- turbine blades are manufactured from corrosion resistant materials.

b) details of design and manufacturing:

- rotors and stators must meet the following conditions:

- II components must be free from defects in construction and will be manufactured and assembled with tolerances and games so as to allow thermal expansion and minimize distortions housing and rotors in all operating conditions;

- when using the labyrinth seals, steam supply piping sealing system should be arranged so that condensed steam does not come into turbine;

- particular attention should be paid connecting piping turbine stators so as to avoid abnormal operating workload;

- at the changes of the sections of rotor, carcasses and of blades bases, the threads will be very well finished, and holes in the discs will be well rounded and polished.

- bearings :

- turbine bearings must be positioned so as their lubricate system not to contribute to overheating adjacent hot elements;

- have prevented oil dripping on hot parts;

- also at the registry appreciation can adapt cooling system to ensure cooling bearings after stopping the turbine;

c) Turning gearing system:

- main turbine propulsion must be equipped with a system allowing its turning in both directions and auxiliary rotors coud be rotated by hand;

- turning-gearing system must have a couplingdecoupling view indicator visible from the platform control;

- must be provided safeguards to prevent start the turbine when turning gearing sytem is coupled.

d) reversing turbine propulsion:

- main turbine propulsion must have enough power to provide backstop. It is considered reversing power turbine can provide enough when reversing speed equivalent to $70 \%$ of maximum forward speed for a period of at least 30 minutes; - propulsion system with reversing gearbox, control pich propeller or electrical transmission, will not cause any overload of the propulsion machinery at the astern running;

- during reversing, the main condenser and reversing turbine do not have to excessively overheating;

e) protectie (Interlock): admiterea simultană a aburului în turbină a mers mai departe și de mers înapoi turbina, va fi împiedicată de protecție. O scurtă suprapunere între supapele de deschidere înainte și invers poate fi permisă.

f)protection against low lubrication to the bearings:

- main reversing turbines must be equipped with quick closing steam valves when the lubrication

DOI: 10.21279/1454-864X-16-I1-038

(c) 2015. This work is licensed under the Creative Commons Attribution-Noncommercial-Share Alike 4.0 License. pressure of bearings, descend below the minimum permissible running;

- This system should enable admision of steam in reversing turbine for braking the ship;

B) Gas Turbines:

a) construction materials for gas turbines approved by classification societies:

- these materials must meet the operational requirements of each item. At the choice of materials must be taken into account phenomena such as creep, thermal stress, oxidation and corrosion undergone by each element during operation. The manufacturer must provide information about appropriate qualities of the materials to the classification society such as details about their chemical composition, mechanical properties and thermal treatment. In the case of composite materials must be provided the method of manufacture;

- turbine blades must be constructed of materials resistant to corrosion and high temperatures.

b) checking tension or stress analysis:

- calcuation:

- manufacturer shall provide the tensions calculation for each rotor in the toughest operating conditions;

- also must submit to stress analysis for each rotor individually taking into account the concentration of tensions;

- previous results obtained under the service experience can be considered as an alternative to the first two points of analysis;

- ships classification society requires data on the length of service resulting from design calculations which led to these results.

c) The vibrations are monitored continuously, bending vibrations or vibrations values that affect the entire system are unaccepted.

d) details of construction and design:

- rotors and stators:

- all components must be free from construction defects and will be manufactured and assembled with tolerances and games so as to allow thermal expansion and minimize housing and rotors distortions in all operating conditions;

- at the changes of the sections of rotor, carcasses and of blades bases, the threads will be very well finished, and holes in the discs will be well rounded and polished.

- bearings:

- bearings must be positioned so their anointing is not affected by lubricant overheating becouse of gas turbine hot parts;

- have prevented oil dripping on hot parts;

- positioning of the bearings so as to ensure their cooling after stopping of the turbine, to prevent their seizing if necessary; 


\begin{abstract}
"Mircea cel Batran" Naval Academy Scientific Bulletin, Volume XIX - 2016 - Issue 1
Published by "Mircea cel Batran" Naval Academy Press, Constanta, Romania // The journal is indexed in: PROQUEST / DOAJ / DRJI / JOURNAL INDEX / I2OR / SCIENCE LIBRARY INDEX / Google Scholar / Crossref /

Academic Keys / ROAD Open Access / OAJI / Academic Resources / Scientific Indexing Services / SCIPIO
\end{abstract}

- rolling ball bearings (bearings) must be identifiable and shall have a term of usage at least 40,000 hours;

- the turning-gear system must meet the same conditions as the turning-gear system of a steam turbine.

- Protection at low lubrication pressure to the bearings, signals the minimum allowable operating pressure and if the pressure drops below this limit disconnects the load and then stops turbine.

- the rotors fully equipped with disc and blades will be dynamic balanced on a suitable balancing bench relative to the size and weight of rotors. The test is performed with flexible coupling mounted.

Following the classification rules and construction for gas turbines imposed by the German ship classification society, Germanischer Lloyd (GL) turbine bearings must be designed in accordance with the manufacturer's standards for the tasks of loading, so the turbine to operate at full load for a adequate period of time. The bearings must be equipped with appropriate sealing, easy to replace and a reliable lubrication to provide lubrication for a short period of time at normal or exceptional transient such as willful emergency stop, blackout, etc.

Classification societies require continuous monitoring of vibration to the bearings to know their status. Turbine propulsion plants that engages the power turbine propeller propeller or water jet propulsion, torsional vibrations monitoring is required throughout the kinematic chain including the gas turbine. If the turbine manufacturer does not require, the power turbine excitations may be ignored in calculating the torsional vibrations of the shaft.

The quality of lubricate oil and smooth operation of the lubrication plant are are very important for the proper functioning of bearings, classification societies have provided clear rules such as:

- fitting of filters and oil coolers;

- In the lubrication of each camp will be mounted magnetic detectors swarf

- In de lubricate area of each bearing will be mounted magnetic chip detector (MCD);

- water separators will be installed;

- the lubricated system will be arranged and protected so that any oil leakage does not occur on surfaces with temperatures above $220^{\circ} \mathrm{C}$ or on parts in rotation moving;

- mounted installations filters shoud be cleaned without affecting the operation of the turbine and will be provided with sensors for monitoring the pressure difference;

- oil tanks will be fitted with oil level monitoring and low level alarm monitoring system; tank also can be filled with oil without affecting the turbine operation;

- the installation shall be provided with sampled valves for oil analysis.

\section{MAINTENANCE OPERATIONS WHICH KEEP BEARINGS TO WORK PROPERLY}

Vibration monitoring in the bearings area are a good witness regarding their functioning among other phenomena of turbine operation that can induce vibrations in it, such as:

- surging of compressors;

- imbalances ofshafts due to deposits of salt or other impurities from the air, characteristic of marine environment, on the blading rotors of compressors;

- carbon deposits on the turbines bladings;

- critical speeds;

- aerodynamic misalignment between generator and turbine power;

- deterioration of sealing systems in the bearings area, which could lead to oil leaks in the turbine;

- damaged of systems and mechanisms driven by auxiliary gearbox;

- lubrication system malfunction;

In figure 9 is reprezented the vibration monitoring scheme a single shaft gas turbine where vibration monitoring can be seen in the axial and radial bearings areas, relative to the shaft speed and real-time diagnostic.

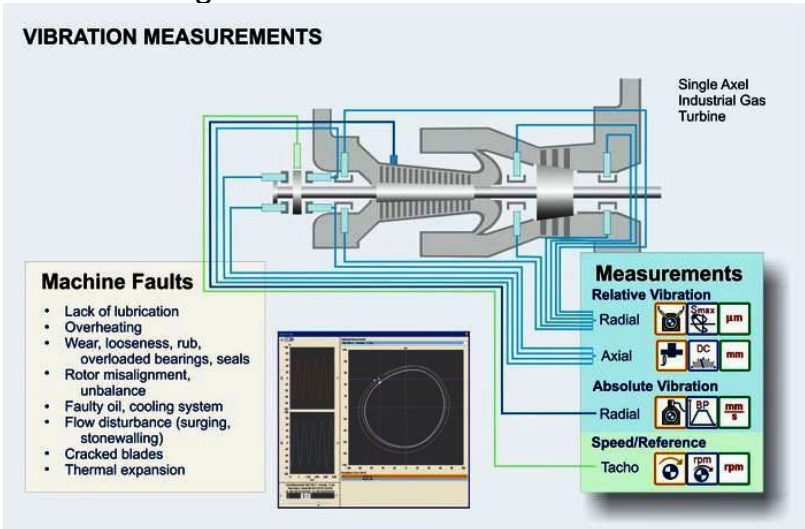

Fig. 9 - Diagnosis and vibration monitoring system in real time product by Brüel \& Kjær Vibro GmbH [3]

Lubricating oil quality is monitored to know if he has changed the chemical composition and lubricating qualities By monitoring emergence of metalic chips in the oil, you can know if the bearings are in good shape or not and if metal impurities from oil can endanger the turbine bearings. Lubrication system is equipped with special filters designed to retain mechanical impurities and water from oil. Magnetic chip detectors (MCD) are positioned in pockets under the oil return line from each bearing. These pokets are provided with self-closing valves that do not allow the oil to drain at fitting/dismantling the 
"Mircea cel Batran" Naval Academy Scientific Bulletin, Volume XIX - 2016 - Issue 1

Published by "Mircea cel Batran" Naval Academy Press, Constanta, Romania // The journal is indexed in: PROQUEST / DOAJ / DRJI / JOURNAL INDEX / I2OR / SCIENCE LIBRARY INDEX / Google Scholar / Crossref /

Academic Keys / ROAD Open Access / OAJI / Academic Resources / Scientific Indexing Services / SCIPIO

detectors for read the samples. In figure 10 it can be seen positioning of the magnetic chip detectors on a standard lubrication system of a gas turbine. When analyzing the collected samples, studying of size, shape and specific magnetic properties of the chips collected are important factors in the diagnosis of bearing condition.

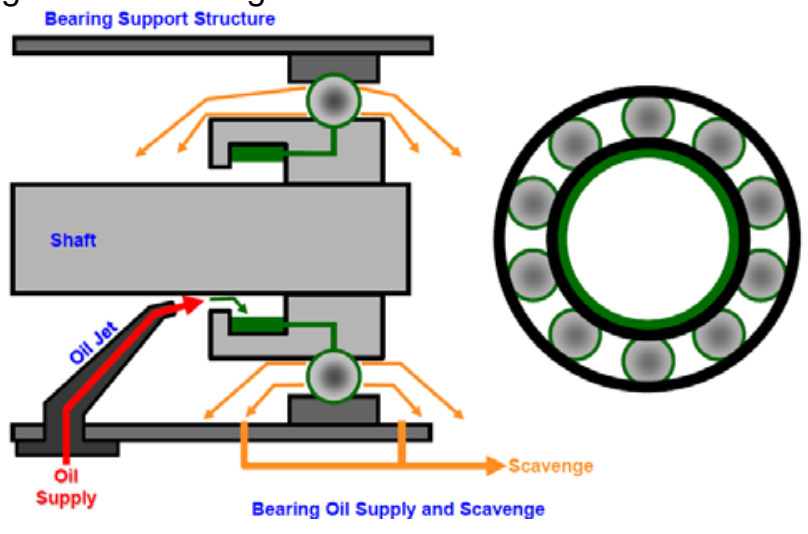

a) oil lubrication circuit bearing

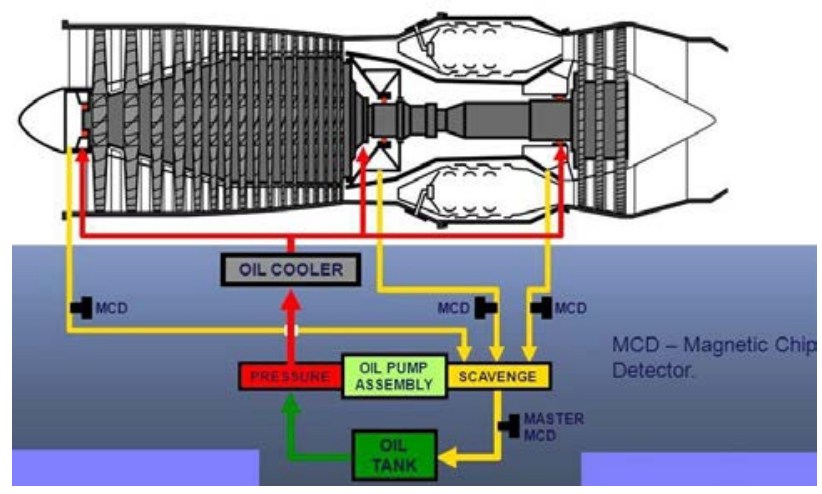

b) Magnetic Chip Detectors positions

Fig. 10 - General scheme of a lubricating system for a gas turbine [15]

Magnetic Chip detectors are of two types: conventional permanent magnet magnetic head (figure 11) and active head electromagnetic powered by a DC electric circuit (figure12a). The last one consists of two electrical pole, first an ferous electrode with magnetic properties which is surrounded by second electric pole isolated from each other (figure 12b). Chips collected by magnetic electrode closes the electrical circuit between the two poles as an electrical switch. With the closed circuit, it signals bearing location, with excess metal chips. This signal should not be regarded as a tdamange of the bearing until not remove the detector and check chips deposit, becouse coud be a single higher particle or accumulation of normal wear if they were dismantled and checked in time.

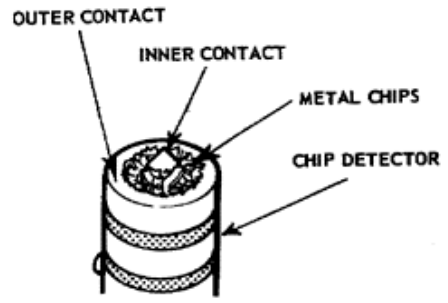

Fig. 11 - Magnetic Chip Detector [18]

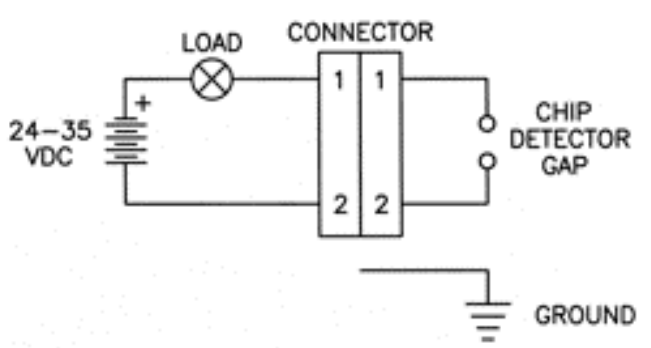

a. Chip gap contacts are isolated from case ground [17]

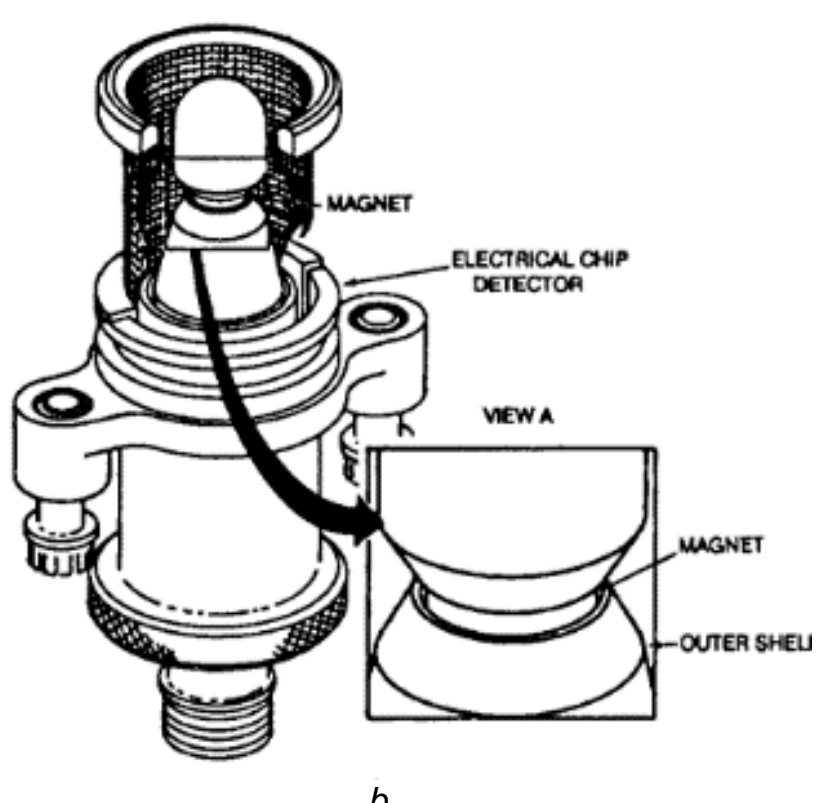

Fig.12 - Electric Chip Detectors (ECDs) [16]

To eliminate reading errors EDC is fed to a pulse circuit that works with a condenser discharging stored energy via the contact bridge formed by deposits of Spain, releasing enough heat to break the circuit like a fusible plug. If the discharge circuit interrupted EDC circuit resumes normal operation. In the opposite case is considered significant deposition of swarf and triggers the alarm.

Another type of activ MCD is Quantitative Debris Monitoring-QDM Sensor. These detectors are inductive (figure 13) and monitor both quantitatively and size of these particles, having a mass default upheld. Particles with larger masses 
"Mircea cel Batran" Naval Academy Scientific Bulletin, Volume XIX - 2016 - Issue 1

Published by "Mircea cel Batran" Naval Academy Press, Constanta, Romania // The journal is indexed in:

PROQUEST / DOAJ / DRJI / JOURNAL INDEX / I2OR / SCIENCE LIBRARY INDEX / Google Scholar / Crossref /

Academic Keys / ROAD Open Access / OAJI / Academic Resources / Scientific Indexing Services / SCIPIO

are taken into account. After removing the detector, particles are intact and can be analyzed.
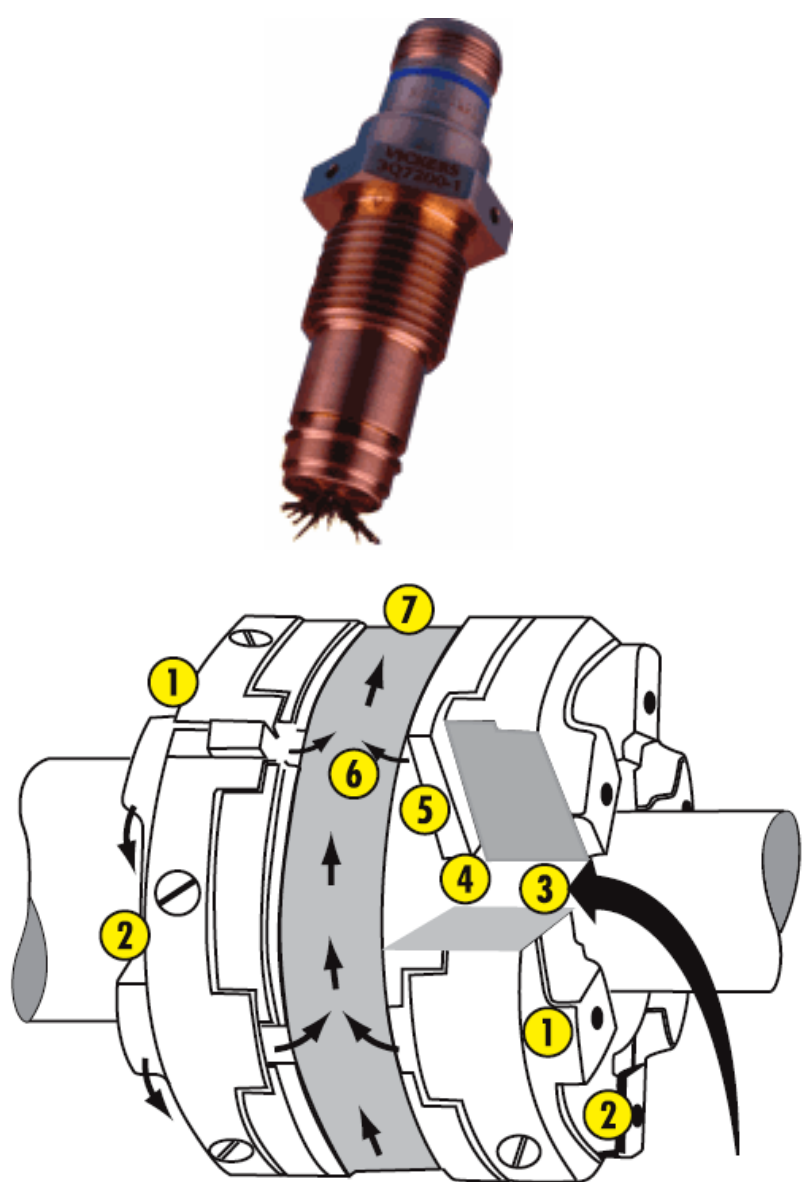

Fig.14 - Thrust bearing typical oil flow path [12, pg.12]

1 - oil enters annulus in base ring; 2 - oil passed trough radial slots in back face of base ring; 3 - oil flows through clearance between base ring bore and shaft; 4 - oil flows to inner diameter of rotating thrust collar; 5 - oil flow between shoes and into the films; 6 - at the collar rim, oil is
Fig.13 - Quantitative Debris Monitoring Sensor [19]

Periodically according to the peculiarities of operation and maintenance of each type of turbine are collected and analyzed oil samples to determine water content.

A typical oil flow path in a thrust bearing it can be seen from figure 14. Oil enters sump and pumped through a filter and cooler and passed through inlet orifice witch controls flow rate.

Excess water in oil can cause dislocation of the oil film. Because of "free radicals" of hydrogen from water molecules can take place microcracking chemical reactions between the rollers and raceways of bearings causing pitting and flaking. In figure 15 is plotted the effect of water in oil for bearing life time.

thrown off into space around the collar; 7 - oil exits tangentially through the discharge opening.

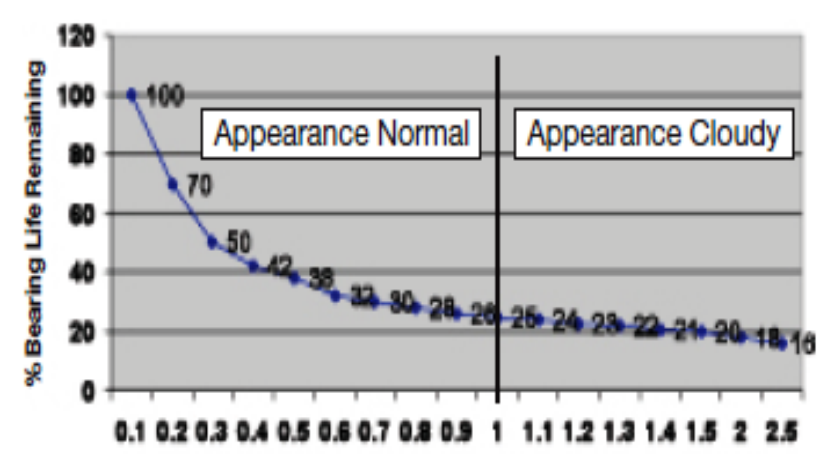

$\%$ Water in Oil

Fig. 15 - Water in oil versus bearing life [20]

\section{CONCLUSIONS}

Classification societies recognize the operational safety of the gas turbines and encourages their use in shipping through the development of rules for classification in the design and construction of gas turbines, classification rules that take into account all aspects of installation on board ships, their operation and maintenance.

Ship classification societies have developed standardized rules for barings of naval propulsion plants that have turbine propulsion machine.

The advantages of using bearings or rolling bearings in the construction of propulsion plants with turbines (detailed in the table below) are taken into account depending on installation requirements.

\begin{tabular}{|c|l|}
\hline Bearings advantages & \multicolumn{2}{|c|}{$\begin{array}{c}\text { Rolling bearings } \\
\text { advantages }\end{array}$} \\
\hline $\begin{array}{l}\text { - radial dimentions } \\
\text { reduced; } \\
\text { cheaper if are not } \\
\text { magnetic type and friction in } \\
\text { operating which allows } \\
\text { easy start; } \\
\text { - lack of self-excited }\end{array}$ \\
\hline
\end{tabular}

222 
"Mircea cel Batran" Naval Academy Scientific Bulletin, Volume XIX - 2016 - Issue 1 Published by "Mircea cel Batran" Naval Academy Press, Constanta, Romania /I The journal is indexed in: PROQUEST / DOAJ / DRJI / JOURNAL INDEX / I2OR / SCIENCE LIBRARY INDEX / Google Scholar / Crossref / Academic Keys / ROAD Open Access / OAJI / Academic Resources / Scientific Indexing Services / SCIPIO

\begin{tabular}{|c|c|}
\hline $\begin{array}{l}\text { therefore does not require } \\
\text { a power supply system; } \\
\text { - have a lower friction; } \\
\text { - noise damping because } \\
\text { of damping capacity; } \\
\text { - can operate at very high } \\
\text { speeds; } \\
\text { - their operation allows } \\
\text { significant misalignment of } \\
\text { the shaft; } \\
\text { - bearings are not } \\
\text { destroyed at fatigue. }\end{array}$ & $\begin{array}{l}\text { instability; } \\
\text { - can take } \\
\text { simultaneously both } \\
\text { forces axial and radial; } \\
\text { - allow the lubricant } \\
\text { sealing; } \\
\text { - simpler and cheaper } \\
\text { because of extensive } \\
\text { standardization. }\end{array}$ \\
\hline
\end{tabular}

Although most industrial turbines are manufactured bearings, because most gas turbines equipping naval propulsion plants are derived from aviation turbines, find rolling bearings and specific monitoring systems. Vibration monitoring systems and magnetic chip detectors becoming more efficient, provides better protection in operation of bearings and increase turbine service period. Regular analysis of oil samples from time prevent bearings wear that can shorten the bearings life remaining for which it was designed.

\section{BIBLIOGRAPHY}

[ 1] American Bureau of Shipping, "Rules for Building and Classing - Steel Vessels, Part 4-Vessel Systems and Machinery/2007/ Chapter 2 - Prime Moves/Section 3 - Gas Turbine / Chapter 3 - Propulsion Maneuvering Machinery/Section 3 - Propulsion Shafting";

[ 2] American Bureau of Shipping, "Guide for Propulsion Systems for LNG Carriers/Section 7 - Dual Fuel Gas Turbine Propulsion System", 2005 and updates February 2014;

[3] Brüel \& Kjær Vibro GmbH , http://www.bkvibro.com/en/condition-monitoring/oil-and-gas-industry/lngplants.html ;

[4] Bureau Veritas, "Rules for the Classification of Steel Ship / PART C - Machinery, Electricity, Automation and Fire Protectionc Chapter 1", July 2011;

[5] Classification society \& IACS | Maritime-Connector.com;

[ 6] Claire Soares, "Gas Turbines A Handbook of Air, Land, and Sea Application",

http://www.gciltraining.com/download-pdf-gas-turbines-a-handbook-of-air-land-and-sea-application-2fs/ ;

[ 7] Farshad Shamoradi, Naser Mohammadi, and Mahdi Heidari KahkeshHome (http://www.powermag.com) / Coal (http://www.powermag.com/category/coal/), „Steam Turbine Rotor Vibration Failures: Causes and Solutions", 04/01/2013;

[ 8] Gene Solver US Navy, "Chapter 7 - Reduction Gears and Related Equipement", http://www.eugeneleeslover.com/ENGINEERING/CHAPTER-7.html ;

[ 9] http://www.omtr.pub.ro/t_cicone/didactic/om_files/OM_AR_II_08_(Lagare)_2011_2spp_part1.pdf ;

[10] Industrial \& Marine Turbine Forecast - Gas \& Steam Turbines, Analysis 4 The Market for Gas Turbine Marine Engines 2010-2019 Product Code \#F649 A Special Focused Market Segment Analysis by:

FORECAST INTERNATIONAL;

[11] International Association of Classsificasion Societies, "Clasification Societies-What, Why and How?", IACS 2011 subject to the terms and conditions shown on the IACS website www.iacs.org.uk;

[12] Kingsbury, Inc., „A General Guide to The Principles, Operation and Toubleshooting of Hydrodynamic Bearings", http://www.kingsbury.com/pdf/universe brochure.pdf ;

[13] Meherwan P. Boyce, "Gas Turbine Engineering Hand Book, Second Edition", Gulf Professional Publishing 2002

[14] Steven R. Schmid (University of Notre Dame) and Karl J. Schmid (John Deere Corporation), " Marine Equipment Tribology", http://home.ufam.edu.br/berti/nanomateriais/8403_PDF_CH36.pdf ;

[15] „Marine Equipment Tribology, , http://home.ufam.edu.br/berti/nanomateriais/8403_PDF_CH36.pdf

[15] Worldwide Marine Engines, http://slideplayer.com/slide/5750479/ ;

[16] www.globalsecurity.org/military/library/policy/army/fm/1-506/Ch5.htm;

[17] www.tedecoindustrial.com/electric.htm;

[18] www.globalsecurity.org/military/library/policy/army/accp/al0993/le6.htm;

[19] www.tedecoindustrial.com/qdm.htm - Engineered Sensors Tedeco Products ;

[20] www.mobilindustrial.com/ind/english/files/tt-turbine-oil-system-care-and-maintenance.pdf - MOBIL /

Turbine Oil System Care \& Maintenance. 